\title{
СОСТАВ И ТЕМПЕРАТУРНЫЙ РЕЖИМ ФОРМИРОВАНИЯ ПОРОД ИНГОЗЕРСКОГО МАССИВА
}

Ниткина Е.А.

Геологический институт КНЦ РАН, Anamumbl,nitkina@rambler.ru

Ингозерский массив сложен преимущественно гнейсами и гранитоидами разного состава и расположен (рис. 1) в северо-восточной части Беломорского подвижного пояса $[1 ; 6 ; 7 ; 5 ; 3]$. Архейские комплексы основания, как картируемые геологически значимые структуры имеют называние тоналит-трондъемит-гнейсового комплекса - ТТГ [7; 9; 4]. Изученные гнейсы Ингозерского массива по петрохимическим характеристикам отвечают тоналитам и трондьемитам, геохимические характеристики распределения редкоземельных элементов схожи с породами ТТГ комплексов, известных на древнейших щитах Мира [12].

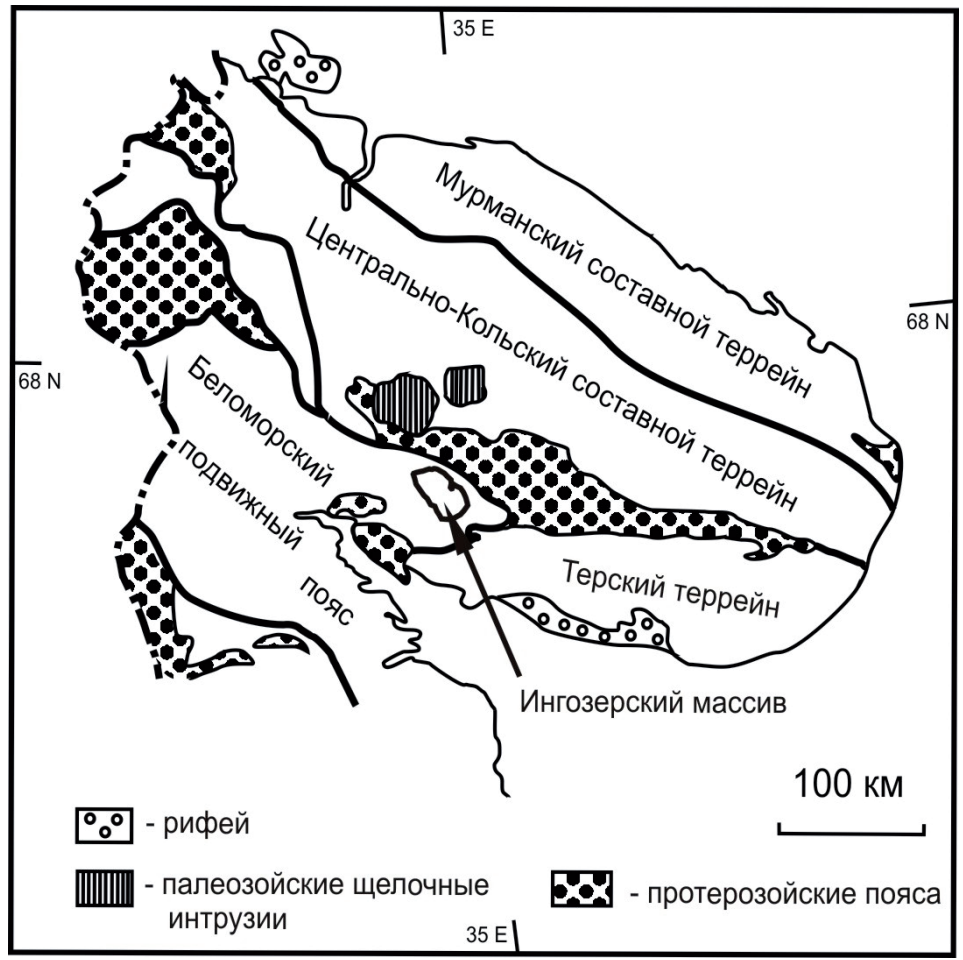

Рис. 1. Схематическая карта Кольского полуострова [2] с изменениями автора.
В ранее проведенных исследованиях $[1 ; 6 ; 5 ; 3 ; 9 ; 4]$ в пределах Ингозерского массива выделены следующие типы пород: биотитовые, биотит-амфиболовые, амфиболбиотитовые гнейсы, гранитогнейсы, амфиболиты, гранодиориты и пегматиты. Биотитовые, амфиболбиотитовые и биотит-амфиболовые гнейсы являются метаморфизованными и рассланцованными останцами первичных ТТГ пород [6]. Дайки основного состава, метаморфизованные и рассланцованные совместно с толщами гнейсов, переработаны в полевошпатовые амфиболиты и прорваны телами крупнозернистых гранитов и пегматитов.

По результатам изотопного датирования установлена следующая последовательность геологических процессов Ингозерского массива [8]: $3149 \pm 46$ млн. лет - образование маг-

матического протолита биотитовых гнейсов; $2727 \pm 5-2725 \pm 2$ млн. лет - второй этап внедрения тоналитов или метаморфизм и деформации пород, связанные с внедрением даек основных пород; 2697士9 $2667 \pm 7$ млн. лет - рассланцевание, метаморфизм, деформация пород, происходившие одновременно с внедрением гранитоидных тел; $2615 \pm 8$ млн. лет - внедрение тел гранитов; $2549 \pm 30$ млн. лет - послойная микроклинизация биотитовых гнейсов.

Данное исследование направлено на оценку температуры кристаллизации гранитоидов Ингозерского массива. Пробы для оценки температуры кристаллизации пород были отобраны из биотитовых гнейсов (Н-10-01), амфибол-биотитовых гнейсов (Н-10-07) и биотит-амфиболовых гнейсов (Н-10-08) и гранито-гнейсов (Н-10-05).

Для определения температуры кристаллизации гранитоидов Ингозеского массива использовался метод определения температуры кристаллизации гранитоидов по насыщению цирконием [13]. Для этого необходимы определения содержаний петрогенных элементов и $\mathrm{Zr}$ в породах. Определение петрогенных элементов проводилось в химико-аналитической лаборатории ГИ КНЦ РАН. Распределение редкоземельных элементов в породах ТТГ комплекса Ингозерского массива было изучено с использованием данных, полученных в Аналитическом центре ИГМ СО РАН по методике [10]. 
Таблица 1. Содержание петрогенных (мас. \%) и редких элементов (г/т) в гранитоидах Ингозерского массива.

\begin{tabular}{|c|c|c|c|c|}
\hline & H-10-01 & H-10-07 & H-10-08 & H-10-05 \\
\hline $\mathrm{SiO}_{2}$ & 71.12 & 67.81 & 66.55 & 73.5 \\
\hline $\mathrm{TiO}_{2}$ & 0.26 & 0.49 & 0.47 & 0.20 \\
\hline $\mathrm{A}_{2} 2 \mathrm{O}_{3}$ & 14.22 & 13.90 & 13.85 & 12.15 \\
\hline $\mathrm{Fe} 2 \mathrm{O}_{3}$ & 0.22 & 0.11 & 1.09 & 0.93 \\
\hline $\mathrm{FeO}$ & 2.94 & 4.77 & 4.40 & 3.27 \\
\hline $\mathrm{MnO}$ & 0.037 & 0.075 & 0.059 & 0.036 \\
\hline $\mathrm{MgO}$ & 0.65 & 1.69 & 2.00 & 0.27 \\
\hline $\mathrm{CaO}$ & 2.46 & 3.95 & 4.29 & 1.29 \\
\hline $\mathrm{Na}_{2} \mathrm{O}$ & 5.20 & 4.13 & 4.26 & 3.34 \\
\hline $\mathrm{K}_{2} \mathrm{O}$ & 1.70 & 1.37 & 1.32 & 3.93 \\
\hline $\mathrm{La}$ & 18.90 & 11.37 & 30.17 & 4.2 \\
\hline $\mathrm{Ce}$ & 34.89 & 27.22 & 53.86 & 7.8 \\
\hline $\operatorname{Pr}$ & 3.98 & 3.28 & 6.22 & 0.91 \\
\hline $\mathrm{Nd}$ & 12.83 & 12.36 & 20.66 & 3.3 \\
\hline $\mathrm{Sm}$ & 1.98 & 2.34 & 3.06 & 0.60 \\
\hline $\mathrm{Eu}$ & 0.46 & 0.76 & 0.77 & 0.39 \\
\hline $\mathrm{Gd}$ & 1.27 & 2.43 & 2.62 & 0.62 \\
\hline $\mathrm{Tb}$ & 0.17 & 0.37 & 0.34 & 0.085 \\
\hline Dy & 0.71 & 1.92 & 1.41 & 0.48 \\
\hline Ho & 0.13 & 0.37 & 0.25 & 0.082 \\
\hline Er & 0.31 & 0.88 & 0.68 & 0.18 \\
\hline $\mathrm{Tm}$ & 0.05 & 0.13 & 0.09 & 0.027 \\
\hline $\mathrm{Yb}$ & 0.30 & 0.88 & 0.56 & 0.16 \\
\hline $\mathrm{Lu}$ & 0.04 & 0.13 & 0.08 & 0.027 \\
\hline $\mathrm{Zr}$ & 124 & 131 & 120 & 36 \\
\hline
\end{tabular}



Рис. 2. Распределение РЗЭ, нормированное к хондриту [11], для биотитовых (Н-10-01), амфибол-биотитовых (H-10-07) и биотит-амфиболовых (Н-10-08) гнейсов, и гранито-гнейсов (H-10-05) TTG комплекса Ингозерского массива (анализы выполнены в ИГМ СО РАН). 
Химический состав пород представлен в таблице (табл. 1). Для исследованных гнейсов Ингозерского массива точки химических анализов гнейсов ложатся в поля тоналитов и трондьемитов, высокое содержание легких редкоземельных элементов и отсутствие Еu аномалии (рис. 2) говорит о происхождение пород из обогащенных источников без существенной роли фракционной кристаллизации [8] и схоже с таковыми для пород комплексов ТТГ Мира [12]. Для гранито-гнейсов характерно высокое содержание К и низкое Са. В распределении редкоземельных элементов присутствует постепенное снижение содержаний элементов от легких к тяжёлым и положительная Еu аномалия (рис. 2).

Используя содержания Zr в породах были рассчитаны значения температуры кристаллизации гранитоидного расплава по насыщению цирконием с использованием термометра [13]: при кристаллизации пород комплекса TTG от 735 до $755^{\circ} \mathrm{C}$, и при кристаллизации секущих гранитных тел $-670{ }^{\circ} \mathrm{C}$.

Расчетные значения температуры по насыщению $\mathrm{Zr}$ для гранитов, содержащих ксеногенные ядра циркона, наиболее близки к температурам образования кислого расплава, напротив, оценки T по гранитам, лишенным ксеногенных цирконов, отражают условия насыщения и занижены в сравнении с температурами плавления [10].

Таким образом, температура выплавления гранитоидов Ингозерского массива была $\sim 750{ }^{\circ} \mathrm{C}$, а секущих гранитных тел - не менее $670{ }^{\circ} \mathrm{C}$.

Работа подготовлена при поддержке программы президиума РАН № 19 «Фундаментальные проблемы геолого-геофизического изучения литосферных процессов».

\section{Литература}

1. Батиева И.Д., Бельков И.В. Гранитоидные формации Кольского полуострова. // Очерки по петрологии, минералогии и металлогении Кольского полуостров. Л.: Наука. 1968. с. 5-143.

2. Балаганский В.В. Главные этапы тектонического развития северо-востока Балтийского щита в палеопротерозое. Автореф. дисс. ... д.г.-м.н. СПб. 2002. 32 с.

3. Бельков И.В., Загородный В.Г., Предовский А.А. и др. Стратиграфическое расчленение и корреляция докембрия С-В части Балтийского щита. Л.: Наука. 1971. С. 141-150.

4. Докембрийская тектоника северо-восточной части Балтийского щита (Объяснительная записка к тектонической карте С-В части Балтийского щита м-ба 1:500000). / отв. редактор Ф.П. Митрофанов. Апатиты: КФАН СССР. 1992. 112 C.

5. Загородный В.Г., Радченко А.Т. Принципы и главные черты тектонического районирования северо-восточной части Балтийского щита. // Тектоника и глубинное строение северо-восточной части Балтийского щита. Апатиты: КФАН СССР. 1978. С. 3-12.

6. Козлов Н.Е., Сорохтин Н.О., Глазнев В.Н., Козлова Н.Е., Иванов А.А., Кудряшов Н.М., Мартынов Е.В., Тюремнов В.А., Матюшкин А.В., Осипенко Л.Г. Геология архея Балтийского щита. СПб.: Наука. 2006. 329 с.

7. Митрофанов Ф.П. Современные проблемы и некоторые решения докембрийской геологии кратонов // Литосфера. 2001. № 1. C. 5-14.

8. Ниткина Е.А., Баянова Т.Б. Изотопно-геохронологическое изучение пород Ингозерского массива (Кольский полуостров) // Вестник МГТУ. В печати.

9. Объяснительная записка к геологической карте северо-восточной части Балтийского щита масштаба 1:500 000 / Ред. Ф.П. Митрофанов. Апатиты: Изд. КНЦ РАН, 1994. 95 с.

10. Туркина О.М., Капитонов И.Н. Изотопный Lu-Hf состав цирона как индикатор источников расплава для палеопротерозойских коллизионных гранитов // Геология и геофизика. 2017. Т. 58. № 2. С. 181-199.

11. Boynton W. V. Chapter 3. Cosmochemistry of the rare earth elements: Meteorite studies, In Rare Earth Element Geochemistry (P. Henderson, ed.), (Developments in Geochemistry 2), Elsevier, Amsterdam. 1985. P. 115-1522.

12. Moyen J.-F. \& Martin H. Forty years of TTG research // Lithos. 148. 2012. P. 312-336.

13. Watson E.B., Harrison T.M. Zircon saturation revisited: temperature and composition effects in a variety of crustal magma types // Earth and Planetary Science Letters. 1983. V. 64. P. 295-304. 